\title{
UJI EFEK ANALGESIK EKSTRAK KULIT BATANG POHON MATOA (Pometia pinnata) PADA MENCIT (Mus musculus)
}

\author{
${ }^{1}$ Rafly F. Lumintang \\ 2Jane Wuisan \\ ${ }^{2}$ Pemsy M. Wowor
}

\author{
${ }^{1}$ Kandidat Skripsi Fakultas Kedokteran Universitas Sam Ratulangi Manado \\ ${ }^{2}$ Bagian Farmakologi Fakultas Kedokteran Universitas Sam Ratulangi Manado \\ Email: raflyfranklien@gmail.com
}

\begin{abstract}
Pain is an unpleasant sensation that derives from the complex neurochemical processes in the central and peripheral nervous systems. Side effects of drugs inter alia opioids and NSAIDs can cause serious disorders, therefore, it is necessary to find and develop other effective analgesic drugs with low toxicity. In Indonesia, matoa (Pometia pinnata) is known as a typical plant in Papua especially in West Papua. In some countries, parts of matoa plants are used as traditional medicine. This study aimed to determine the analgesic effect of matoa bark extract (Pometia pinnata) on mice Mus musculus. This was an experimental study. Nine male mice weighed $30 \mathrm{~g}$ were divided into 3 groups, each consisted of 3 mice. Group I, the negative control group, was given aquadest; group II, the positive control group, was given aspirin solution; and group III, the treated group, was given matoa bark extract. Analgesic effect was determined by counting the mice movements (licking their back legs or jumping) during 1 minute in a beaker with a temperature of $55^{\circ} \mathrm{C}$. The results showed that after 30 minutes the average number of movements of the treated group decreased from 22 times to 19.3 times, and continued to decrease until 1 movement after 120 minutes. Conclusion: Matoa bark extract showed analgesic effect on mice Mus musculus.
\end{abstract}

Keywords: analgesic effect, matoa bark, mice

\begin{abstract}
Abstrak: Nyeri adalah sensasi yang tidak menyenangkan yang berasal dari proses neurokimia kompleks di sistem saraf pusat dan perifer. Opioid dan golongan AINS dapat menimbulkan efek samping yang cukup berat; oleh karena itu, diperlukan obat analgesik yang efektif dengan toksisitas rendah. Di Indonesia, matoa (Pometia pinnata) dikenal sebagai tanaman khas Papua terutama Papua Barat. Di beberapa negara, bagian-bagian dari tanaman matoa telah digunakan sebagai obat tradisional. Penelitian ini bertujuan untuk mengetahui efek analgesik ekstrak kulit batang pohon matoa (Pometia pinnata) pada mencit Mus musculus. Penelitian ini menggunakan metode eksperimental. Sembilan ekor mencit jantan dengan berat rata-rata $30 \mathrm{~g}$ dibagi atas 3 kelompok hewan uji yang masing-masing terdiri dari 3 ekor mencit. Kelompok I yaitu kelompok kontrol negatif diberikan akuades; kelompok II yaitu kelompok kontrol positif diberikan larutan aspirin; dan kelompok III yaitu kelompok perlakuan diberikan ekstrak kulit batang matoa. Efek analgesik berupa jumlah gerakan mencit selama 1 menit saat diletakan di dalam beker dengan suhu tetap $55^{\circ} \mathrm{C}$. Gerakan yang dihitung berupa gerakan menjilat kaki belakang atau meloncat. Hasil penelitian menunjukkan bahwa pada menit ke-30 terjadi penurunan rerata jumlah respon gerakan mencit dari 22 kali menjadi 19,3 kali yang terus berkurang hingga menit ke-120 dimana hanya terdapat 1 gerakan. Simpulan: Ekstrak kulit batang pohon matoa memiliki efek analgesik pada mencit Mus musculus.
\end{abstract}

Kata kunci: efek analgesik, kulit batang matoa, mencit 
Nyeri adalah sensasi yang tidak menyenangkan yang berasal dari proses neurokimia kompleks di sistem saraf pusat dan perifer. Obat antiinflamasi nonsteroid (AINS) dan opioid digunakan dalam penanganan nyeri ringan hingga sedang dan berat. Obat-obat ini memiliki keterbatasan akibat efek sampingnya yang serius. Opioid dapat menyebabkan depresi pernapasan, euforia, toleransi dan ketergantungan, sementara itu AINS dapat menyebabkan iritasi gastrointestinal dan gangguan ginjal. Oleh karena itu, perlu untuk menemukan dan mengembangkan obat yang efektif dengan toksisitas rendah. ${ }^{1}$

Pengobatan herbal masih menjadi pilihan utama sekitar $75-80 \%$ populasi negara berkembang pada pelayanan kesehatan primer. Hal ini disebabkan penerimaan kebiasaan (adat) yang lebih baik, lebih mudah diperoleh, lebih dapat diterima oleh tubuh dan efek samping yang relatif rendah. Beberapa tahun terakhir terlihat peningkatan penggunaan pengobatan herbal pada negara berkembang. World Health Organization (WHO) mendorong penggunaan obat herbal yang terbukti aman dan efektif pada program pelayanan kesehatan di negara sedang berkembang karena potensi besar yang dimiliki untuk melawan berbagai penyakit. ${ }^{1}$

Di Indonesia, matoa (Pometia pinnata) dikenal sebagai tanaman khas Papua dan menjadi flora identitas Provinsi Papua Barat. ${ }^{2}$ Tanaman ini tersebar luas di seluruh dunia dan di beberapa negara bagianbagian dari tanaman matoa digunakan sebagai obat tradisional. Di Papua New Guinea, kulit batang yang dikunyah digunakan untuk mengobati luka bakar. Di Fiji, ekstrak daun dan kulit batang digunakan untuk mengobati berbagai jenis penyakit, termasuk gangguan perut, diare, disentri, penghilang nyeri (tulang, otot, sendi, dada, sakit kepala), demam, flu, diabetes, dan ulkus di mulut. Di Tonga, infusa dari kulit batang digunakan untuk mengobati diare pada anak-anak, gangguan di perut, batuk yang disertai demam dan konstipasi, dan daunnya juga digunakan untuk pengobatan. Di Serawak Malaysia, matoa digunakan sebagai pengobatan tradisional untuk cacar air (chicken pox), dimana pasien dimandikan dengan ekstrak air panas dari kulit batang. ${ }^{3}$ Penelitian terbaru juga menunjukkan bahwa ektrak daun matoa berpotensi sebagai obat infeksi HIV. ${ }^{4}$ Berdasarkan data diatas, peneliti tertarik untuk melakukan uji analgetik ekstrak kulit batang pohon matoa pada mencit.

\section{METODE PENELITIAN}

Penelitian ini bersifat eksperimental dan dilaksanakan pada bulan September 2013 - Januari 2014 di Laboratorium Farmakologi Fakultas Kedokteran Universitas Sam Ratulangi Manado.

Bahan yang digunakan ialah ekstrak kulit batang matoa yang paling luar (Gambar 1). Mencit yang digunakan ialah mencit jantan Mus musculus dengan berat rata-rata 30 gram dan dibagi atas 3 kelompok hewan uji yang masing-masing terdiri dari 3 ekor mencit. Kelompok I yaitu kelompok kontrol negatif diberikan akuades; kelompok II yaitu kelompok kontrol positif diberikan larutan aspirin; dan kelompok III yaitu kelompok perlakuan diberikan ekstrak kulit batang matoa.

Obat analgesik yang digunakan ialah aspirin yang dibuat dalam bentuk larutan sehingga dalam $0,5 \mathrm{~mL}$ terkandung $0,3 \mathrm{mg}$ aspirin. Dosis ekstrak kulit batang matoa yang digunakan $50 \mathrm{mg}$ per ekor mencit dalam satu kali pemberian sedangkan larutan aspirin $0,5 \mathrm{~mL}$ dalam satu kali pemberian. Efek analgesik berupa jumlah gerakan mencit selama 1 menit saat diletakan di dalam dengan suhu tetap $55^{\circ} \mathrm{C}$. Gerakan yang dihitung berupa gerakan menjilat kaki belakang atau meloncat. 


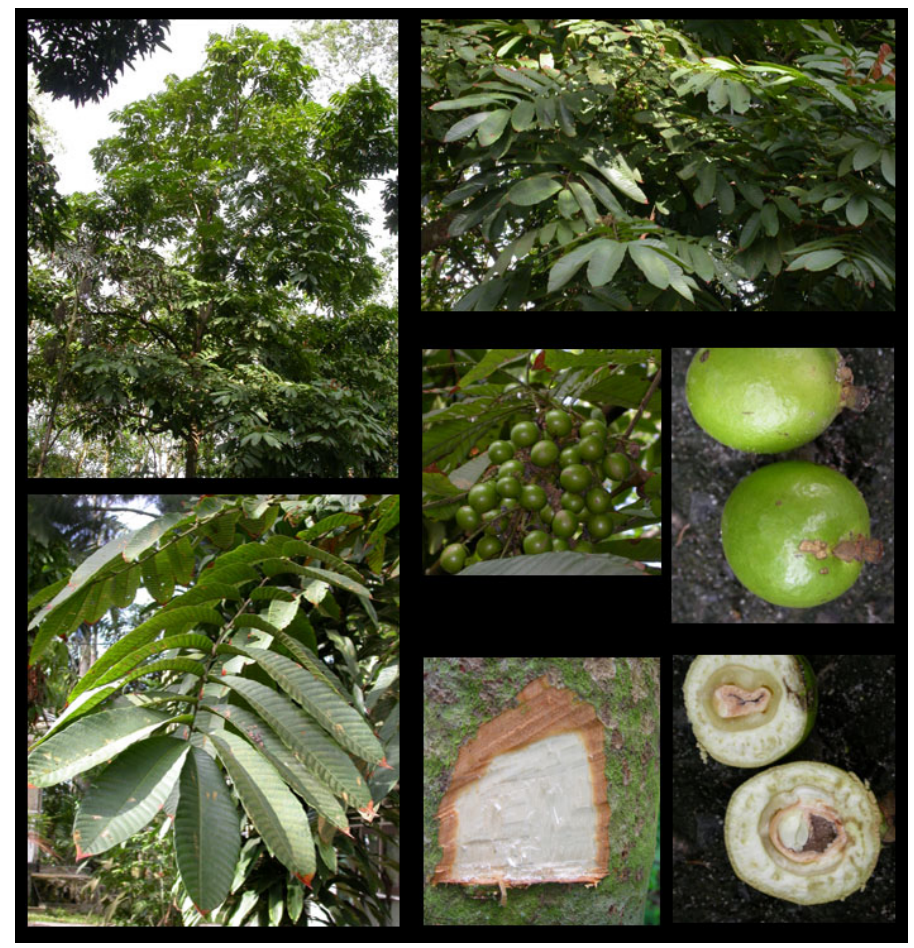

Gambar 1. Tanaman Matoa (Pometia pinnata)

\section{HASIL PENELITIAN}

Pengamatan dilakukan terhadap 3 kelompok hewan uji yang masing-masing terdiri dari 3 ekor mencit. Data berupa jumlah gerakan melompat atau menjilat kaki belakang selama satu menit sebagai respon terhadap pemberian panas.

Hasil pengamatan pada kelompok kontrol negatif, yaitu kelompok mencit yang diberi akuades, didapatkan rerata mencit menjilat kaki belakang atau melompat sebanyak 20,7 kali sebelum pemberian akuades. Setelah pemberian akuades rerata gerakan mencit menurun dibanding sebelum pemberian akuades. Pada menit ke-30 setelah pemberian akuades rerata gerakan sebanyak 19 kali dalam satu menit penghitungan. Pada pengamatan menit ke-60 rerata gerakan 12,3 kali, pada menit ke-90 rerata gerakan 11,3, dan pada menit ke-120 rerata gerakan 10 kali dalam satu menit (Tabel 1).

Hasil pengamatan pada kelompok kontrol positif, yaitu kelompok mencit yang diberi larutan aspirin, didapatkan rerata mencit menjilat kaki belakang atau melompat sebanyak 23,3 kali sebelum pemberian larutan aspirin. Setelah pemberian larutan aspirin rerata gerakan mencit menurun dibanding sebelum pemberian. Pada menit ke-30 setelah pemberian larutan aspirin rerata gerakan sebanyak 18,7 kali dalam satu menit penghitungan. Pada pengamatan menit ke60 rerata gerakan 16 kali, pada menit ke-90 rerata gerakan 3,3 kali dan pada menit ke120 rerata gerakan 1,3 kali dalam satu menit (Tabel 2).

Hasil pengamatan pada kelompok perlakuan, yaitu kelompok mencit yang diberi larutan ekstrak kulit batang pohon matoa, didapatkan rerata mencit menjilat kaki belakang atau melompat sebanyak 22 kali sebelum pemberian larutan ekstrak kulit batang pohon matoa. Setelah pemberian larutan ekstrak rerata gerakan mencit menurun dibanding sebelum pemberian. Pada menit ke-30 setelah pemberian larutan ekstrak rerata gerakan sebanyak 19,3 kali dalam satu menit perhitungan. Pada pengamatan menit ke-60 rerata gerakan 8 kali, pada menit ke-90 rerata gerakan 5,3 kali dan pada menit ke120 rerata gerakan 1 kali dalam satu menit (Tabel 3). 
Tabel 1. Hasil pengamatan respon kelompok kontrol negatif

\begin{tabular}{cccccc}
\hline \multirow{2}{*}{ Subjek } & \multicolumn{4}{c}{ Jumlah respon mencit (menjilat kaki atau melompat) } \\
\cline { 2 - 6 } & Sebelum & \multicolumn{4}{c}{ Setelah perlakuan (Pemberian akuades) } \\
\cline { 2 - 6 } & perlakuan & 30 menit & 60 menit & 90 menit & 120 menit \\
\hline I & 22 & 20 & 13 & 11 & 10 \\
II & 20 & 18 & 12 & 12 & 11 \\
III & 20 & 19 & 12 & 11 & 9 \\
Jumlah & 62 & 58 & 37 & 34 & 30 \\
Rerata & 20,7 & 19 & 12,3 & 11,3 & 10 \\
\hline
\end{tabular}

Tabel 2. Hasil pengamatan respon kelompok kontrol positif

\begin{tabular}{cccccc}
\hline \multirow{2}{*}{ Subjek } & \multicolumn{5}{c}{ Jumlah respon mencit (menjilat kaki atau melompat) } \\
\cline { 2 - 6 } & Sebelum & \multicolumn{4}{c}{ Setelah perlakuan (Pemberian aspirin) } \\
\cline { 2 - 6 } & perlakuan & 30 menit & 60 menit & 90 menit & 120 menit \\
\hline I & 24 & 18 & 13 & 3 & 0 \\
II & 26 & 18 & 16 & 4 & 3 \\
III & 20 & 20 & 19 & 3 & 1 \\
Jumlah & 70 & 56 & 48 & 10 & 4 \\
Rerata & 23,3 & 18,7 & 16 & 3,3 & 1,3 \\
\hline
\end{tabular}

Tabel 3. Hasil Pengamatan Respon Kelompok Ekstrak

\begin{tabular}{cccccc}
\hline \multirow{2}{*}{ Subjek } & \multicolumn{5}{c}{ Jumlah respon mencit (menjilat kaki atau melompat) } \\
\cline { 2 - 6 } & Sebelum & \multicolumn{4}{c}{ Setelah perlakuan (Pemberian ekstrak) } \\
\cline { 2 - 6 } & perlakuan & 30 menit & 60 menit & 90 menit & 120 menit \\
\hline I & 21 & 20 & 10 & 7 & 2 \\
II & 20 & 15 & 6 & 3 & 0 \\
III & 25 & 23 & 8 & 6 & 1 \\
Jumlah & 66 & 58 & 24 & 16 & 3 \\
Rerata & 22 & 19,3 & 8 & 5,3 & 1 \\
\hline
\end{tabular}

Hasil rerata jumlah respon gerakan mencit yang diperoleh dibuat dalam bentuk grafik (Gambar 2). Efek analgesik ekstrak kulit batang pohon matoa masih terlihat hingga menit ke-120, sedangkan efek dari akuades sudah tidak terlihat pada menit ke60 .

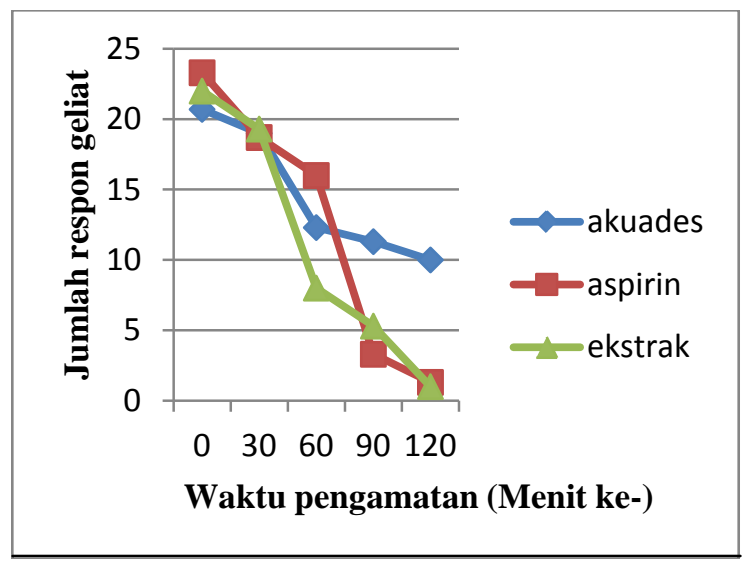

Gambar 2. Grafik rerata jumlah respon gerakan mencit pada setiap pengamatan 


\section{BAHASAN}

Dalam penelitian ini telah dilakukan pengujian efek analgesik dari ekstrak kulit batang pohon matoa terhadap mencit, dengan akuades sebagai kontrol negatif dan aspirin sebagai kontrol positif. Pengujian efek analgesik ini dilakukan untuk melihat kemampuan suatu bahan dalam menekan rasa nyeri pada hewan uji yang diberi rangsangan. Rangsangan yang diberikan berupa rangsangan panas dengan suhu $55^{\mathrm{O}} \mathrm{C}$, kemudian dilihat respon hewan uji untuk menghindari rangsangan yaitu dengan menjilat kaki belakangnya atau melompat.

Kelompok mencit yang diberikan akuades menunjukkan bahwa pada menit ke-30 terjadi perubahan dari sebelumnya yaitu 20,7 kali menjadi 19, kemudian selanjutnya tidak lagi memberikan efek analgesik yang berarti karena pada menit ke-60, ke-90, dan menit ke-120 tidak terjadi perubahan berarti dari 12,3 kali menjadi 11,3 dan pengamatan terakhir yaitu 10 kali. Dengan demikian, pemberian akuades tidak memperlihatkan efek analgesik karena perubahan respon gerakan mencit sangat kecil (Tabel 1).

Pada mencit kelompok kontrol positif dengan pemberian aspirin terlihat bahwa sebelum perlakuan, rerata jumlah respon gerakan mencit 23,3 kali. Pada menit ke-30 turun menjadi 18,7 selanjutnya menit ke-60 menjadi 16 kali dan menit ke-90 menjadi 3,3 kali dan pada pengamatan terakhir yaitu menit ke-120 menjadi 1,3 kali (Tabel 2). Dengan demikian, efek analgesik pada mencit kelompok kontrol positif yang diberikan aspirin dimulai pada menit ke-30 dan berlangsung terus sampai mencapai maksimal pada menit ke-120.

Pengujian pada kelompok ekstrak menunjukkan bahwa pada menit ke-30 terjadi penurunan rerata jumlah respon gerakan mencit dari 22 kali menjadi 19,3 kali. Rerata jumlah respon gerakan ini terus berkurang sampai menit ke-120 yaitu hanya terdapat 1 gerakan. Dengan demikian, efek analgesik pada mencit dengan pemberian ekstrak kulit batang pohon matoa mulai terlihat pada menit ke-30 dan terus berlangsung pada menit ke-60, menit ke-90 dan mencapai maksimal pada menit ke-120 (Tabel 3).

Berdasarkan hasil pengujian diatas, didapatkan bahwa efek analgesik dari ekstrak kulit batang pohon matoa dan aspirin mulai terlihat pada menit ke-30, sedangkan efek maksimal keduanya yaitu pada menit ke-120. Dalam penelitian ini, ekstrak kulit batang pohon matoa memberikan efek analgesik sedikit lebih baik dari aspirin.

Kulit batang pohon matoa mengandung saponin dan tanin. ${ }^{3}$ Melalui banyak penelitian, saponin dan tanin diketahui memiliki efek analgesik. Efek analgesik tanin bekerja melalui penghambatan siklooksigenase-2 (Cox-2) yang selanjutnya menghambat biosintesis prostaglandin. $^{5}$

Biosintesis prostaglandin dimulai dari rangsang yang berupa kimiawi dan termik menyebabkan kerusakan membran sel sehingga enzim fosfolipase diaktifkan untuk mengubah fosfolipid dalam membran sel menjadi asam arakhidonat dan selanjutnya disiklisasi menjadi prostaglandin endoperoksida siklik dalam bentuk PGG2 yang merupakan prazat untuk pembentukan semua senyawa prostaglandin dengan bantuan enzim siklooksigenase. Peroksida dari PGG2 ini melepaskan radikal bebas oksigen yang juga berperan pada timbulnya rasa nyeri. Dari PGG2 diubah menjadi PGH2 dengan bantuan enzim endoperoksida isomerase dan peroksidase. Dari PGH2 ini akan dibentuk secara langsung prostaglandin primer yaitu PGE2, PGF2, dan PGD2. Dari PGE terbentuk prostaglandin $\mathrm{A}, \mathrm{C}$ dan $\mathrm{B}$. Mekanisme kerja analgetik ekstrak kulit batang matoa melalui hambatan siklooksigenase, sehingga menyebabkan asam arakhidonat tidak berubah menjadi prostaglandin endoperoksida siklik. Prostaglandin endoperoksida siklik merupakan prazat semua prostaglandin, oleh karena itu bila senyawa itu tidak terbentuk, maka sintesis prostaglandin terhenti. ${ }^{7}$ 


\begin{abstract}
Aktivitas analgesik saponin terlibat pada sistem saraf pusat dan perifer. Saponin secara bermakna memperpanjang waktu reaksi dan menurunkan jumlah geliat mencit yang diinduksi asam asetat menunjukkan aktivitas analgetik di sistem saraf pusat dan perifer. Aktivitas analgesik saponin terjadi dengan peningkatan jumlah serotonin dan GABA otak, melalui penghambatan enzim hidroksilase dopamin beta. ${ }^{6}$
\end{abstract}

\section{SIMPULAN}

Dari hasil penelitian dapat disimpulkan bahwa ekstrak kulit batang pohon matoa (Pometia pinnata) memiliki efek analgesik terhadap mencit Mus musculus.

\section{DAFTAR PUSTAKA}

1. Musa AM, Aliyu AB, Yaro AH, Magaji MG, Hassan HS, Abdullahi MI. Preliminary phytochemical, analgesic and anti-inflammatory studies of the methanol extract of Anisopus mannii (N.E.Br) (Asclepiadaceae) in rodents. Afr J Pharm Pharmacol. 2009;3(8):3748.

2. Departemen Pertanian. Mengenal tanaman matoa (Pometia pinnata). 2012 [cited 2013 Sep 25]. Available from: http://cybex.deptan.go.id/lokalita/meng enal-tanaman-matoa-pometia-pinnata.

3. Thomson LAJ, Randolph RT. Pometia pinnata (tava). Species profiles for Pacific island argoforestry. Permanent Agriculture Resources, 2006; p. 11.

4. Suedee A, Supinya T, Pharkphoom P. Anti-HIV-1 integrase compound from Pometia pinnata leaves. Pharmaceutical Biology. 2013;51(10):1256-61.

5. Sy GY, Alioune DF, William D, Malick G, Khady B, Emmanuel B, Babacar F. Analgesic and anti-inflammatory activity of aqueous root extract Cassia sieberiana D.C. (Caesalpiniaceae). Afr J Pharm Pharmacol. 2009;3(12):651-3.

6. Pal D, Santanu S, Upal KM. Analgesic and anticonvulsant effects of saponin isolated from the leaves of the Clerodendrum infortunatum Linn. in mice. Indian J Exp Biol. 2009;47:7437.

7. Puspitasari H, Listyawati S, Widiyani T. Aktivitas analgetik ekstrak umbi teki (Cyperus rotundus L.) pada mencit putih (Mus musculus L.) jantan. Biofarmasi 2003;1(2):56. 